\title{
Avoiding online game addiction among youngsters
}

\author{
Muhammad Guntur Aji Purnama ${ }^{1, *}$, Oktavia Trian Azizah ${ }^{2}$, Syam Ja'faros Asshadiq ${ }^{3}$ \\ Department of Electrical Engineering, State University of Malang, Malang, Indonesia \\ ${ }^{1}$ kajhex@gmail.com *; ${ }^{2}$ oktaviatrianazizah@ gmail.com; ${ }^{3}$ syamjafaros@ gmail.com \\ * corresponding author
}

\begin{tabular}{|c|c|}
\hline ARTICLE INFO & ABSTRACT \\
\hline $\begin{array}{l}\text { Article history } \\
\text { Received January 11, } 2018 \\
\text { Revised January 22, } 2018 \\
\text { Accepted February 14, } 2018 \\
\\
\text { Keywords } \\
\text { Technology } \\
\text { Online game } \\
\text { Playing } \\
\text { Addicted }\end{array}$ & $\begin{array}{l}\text { Teenagers give a change that is influenced from various activities conducted } \\
\text { outside the family environment that is playing. The development of } \\
\text { information technology has progressed very rapidly, as one form of } \\
\text { technological development that is the internet. In line with the rapid } \\
\text { development of Internet technology is also triggered the development of new } \\
\text { game technology that uses the internet, known as online games, and the online } \\
\text { game market share at most is the age of adolescence because of the difficult age } \\
\text { in controlling themselves or still unstable in doing something. This is why } \\
\text { teenagers are addicted to playing online games. There are factors that affect a } \\
\text { person's online game addiction that is internal factors and external factors. } \\
\text { Internal factors refer to the state of one's self, while external factors refer to } \\
\text { around a person. The case of online game addiction gives a good positive and } \\
\text { negative impact. The positive impacts include the addition of new friends, } \\
\text { proficient in English, increased concentration and high imagination in making } \\
\text { strategies, while the negative impact caused is the lack of socialization } \\
\text { relationship to the environment, being indifferent, the concern for the } \\
\text { surrounding becomes decreased, concentration decreased, and so forth. To } \\
\text { handle someone not to be addicted to playing online games, it is necessary to } \\
\text { take preventive measures such as fostering strong intentions to stop playing } \\
\text { games, changing gaming activities with more useful activities, reducing time } \\
\text { for playing games, reducing time hanging out with fellow gamers, and more etc. }\end{array}$ \\
\hline
\end{tabular}

This is an open access article under the CC-BY-SA license.

\section{Introduction}

Adolescence is a transitional period between childhood and adulthood. Many changes are experienced by children in their teens. These changes can be influenced from various activities conducted outside the family environment that is playing. Playing becomes one of the important activities in the development of children whether physical, emotional, mental, intellectual, creativity, and social. By playing children can learn adaptation to the surrounding environment and easily get what they want[1][2][3]. The development of information technology has progressed very rapidly, as one form of technological development that is the internet. Along with the rapid development of Internet technology also trigger the development of new game technologies that use the Internet, known as an online game. Online game is very popular by all people from the age of children to children, because it can make the users feel something very fun[4].

According to[5] teenagers is a huge market share of online games. As many as 56\% of American students claimed to have played online games. The research in America shows that $97 \%$ of adolescents aged 12 to 17 years play computer games, web, portable, and console. Then according to[6] teenagers aged 12 to 19 years is a tendency to sacrifice education as well as their work to play online games. Online games now have a difference from the old game that can only be played by two people, but along with advances in technology that internet games can be played by many people in the same time [7]. This is the main attraction for game players to switch to online games. In addition, with the types 
- types of games available with an attractive appearance to make the satisfaction of its own for the players, plus if the player can beat his enemy. Game players do not be confused if they do not have facilities at home, because there are many who open the rental services to play games with a standard fee in accordance with the pockets of students. And this becomes a pretty good business opportunity for people who want to open an online game rental business, considering the many enthusiasts, especially teenagers. But the more lease of game play services will make teens easier to play games anywhere and anytime without any time limitations and over time will dependence on the game. There is research conducted in the United States suggests that almost a third of its teenager correspondences play games every day and more severe 7 percent of them spend time playing games for 30 hours each week [6]. This will certainly affect the child's learning hours become reduced, his health becomes disrupted and society with the community is reduced.

Based on the results of some research that has been done can be known if the online game turned out to give a bad enough impact for its users, one of which is causing addiction to its users. There is research conducted by [8] mentioned that the factors that can affect the behavior of addiction to play online games include: self-control, motivation, psychological needs (desire to power), the desire to win the game and loneliness. In Indonesia online games are rife and spread everywhere. The most users are teenagers. This is evident from the number of visitors in the online game rental places that most still use school uniforms. They spend their rest time playing games, forget their obligations as students, forget to eat, and forget to rest. If this is allowed to drag on, it will have a long-term adverse impact - it can be fatal. Therefore it is necessary to prevent someone not addicted to playing online games. In this paper will be discussed cases of online game addiction and how to prevent it.

\section{Online Games}

Online games is the development of the game on a regular computer as a provider of entertainment services in the form of games that can be accessed online without time constraints, and between players can communicate directly [9]. Online gaming is a site where there is a wide range of games that can connect multiple internet users in different places to connect each other at the same time through online communication network[10][11]. Online gaming can be an adventure game, strategy setting, simulation and role play that has certain rules and levels. This allows players to have an equal opportunity to play, interact, and adventure and form their own communities in cyberspace.

Playing online games makes players feel happy because they get psychological satisfaction such as free from social pressure, anxiety, frustration, feel comfortable, peaceful, and happy. Satisfaction gained from the game will make players more interested in playing it [10]. There are some kinds of the online games such as First Person Shooter (FPS), this game is usually a war that uses military sniper. Real-Time Strategy, this game is more emphasis on the strategy game, usually the game plays not only 1 character but many characters. Cross-Platform Online, games that can be played online with different hardware such as need for speed undercover can be played online from PCs as well as hard ware / console games that have connectivity to the internet so it can play on a regular basis online). Browser games, it is a game that is played on a browser like Firefox, opera, IE. Terms where a browser can play this game is the browser already supports JavaScript, php, or flash. Massive Multiplayer Online Games, this game is a game played by many people (> 100 players), every player can interact directly as does the real world.

\subsection{The Characteristics of Online Game Addiction}

Addiction to online games is defined as overuse, obsessive, compulsive and having common problems with gaming activities. According to[12] the definition of game addiction as excessive and repeated use of computers or smartphones that results in social, emotional, and gameplay issues cannot control over gaming activity.

The cause of game addiction is divided into two factors: internal factors and external factors. Here are the internal factors that affect addiction in online games. Desire players to get higher points than their opponents, this is the goal made online games to make players curious with the game so it will continue to play it. Level of bored is high enough to vent to anything else that is by playing online games. Lack of ability to set priorities or manage time in activities. And, Cannot control themselves to playing online games, so make the players forget themselves with the pattern of his life. 
Moreover, the external factors that affect addiction in online games are, the influence of the environment that mostly play online games. Usually influenced by friends at school. Social interaction with the environment is not good, so the teenagers choose to seek their own fun by playing games. And Lack of supervision and attention from parents so that feel neglected and assume all activities that children do is a natural thing.

There are several studies conducted earlier by [13][6][10] about the behavior of online game addicts, from the research note that the common characteristics that exist in the game addict is experiencing problems on his emotional because he cannot control himself when playing online games, low self-care for being too busy with the game so forget the circumstances herself, poor communication skills, lazy, and usually the player is trying to distance himself from a thing. Another research[14], said that there is a worker who is willing to spend time working to play games at work. Of course it disrupts his work activities and becomes obstructed. Addictions to this online game resemble addiction to consume chemicals, when stopped playing the players will feel depressed, mentally disturbed.

\subsection{Negative Impacts}

The impact of online game addiction mainly come to the players. The teenagers are the most addictive games because of the difficult age in controlling themselves or still unstable in doing something when compared with adults, adolescents also have a high level of curiosity, especially on new things. Technological developments are very rapid influence on the spread of online games very quickly too. When you first play the game the players experience joy, feel more challenged, satisfaction, freedom and so forth, from where the players become addicted to playing continuously[15][16]. They are willing not to sleep for hours to sit in front of the computer, so the impact on the physical health of the players is in sight because it is too often viewed screen monitors, hand pain because too often pressing the -button computer, headache from lack of rest, back pain from sitting too long, weight loss because it is too busy with his game, and even obesity caused by uncontrolled eating[17][10].

The other negative impacts are on the psychological state, such as: the social relationships of his school friends are reduced, the disregard of the surrounding environment, the concern for the surrounding becomes decreased, forget the obligation as the learner, the concentration of the lesson becomes decreased and the more fatal is experiencing the stress of losing to the opponent[18][12]. This has troubled the parents are no exception to the teachers because it affects academic achievement the students[19][6]. If online games are done continuously without time constraints can lead to addiction to play games or commonly called game addiction[20] and have a negative effect on the player. There is research conducted[21] in South Korea showing that $73.4 \%$ of 384 respondents and $83.9 \%$ of 706 students are addicted to playing online games.

Moreover, it also has an impact to the family. Addictions to online games can lead to aggressive behavior, either intentionally or unintentionally. In the online game there is violence, a scene approaching sexual [22]. Another impact that arises from online game addiction is the "behavioral effect" in which this effect occurs when players play the game in the form of behavior and action. Players tend to follow and imitate situations like those in the games they likely. This affects to many people around him, especially the family. Teenagers will be stubborn, hard to listen to parenting advice, more do not want to listen to others.

\subsection{Positive Impacts}

Playing online games not only cause adverse effects, but also has a positive impact. According to research on [23] by playing online games players get many new friends who have the same hobby, players become proficient in English because usually the online games using the international language and there will appear the terms - commonly used terms in the game. Another impact is to increase concentration and high imagination in making game strategy so as not to be defeated by enemies, to improve abstract thinking skills, problem solving and logic, eye coordination of hand coordination and spatial visual ability, teaching children, managing hypothesis, teamwork and cooperation while playing with others, and real-world simulation skills[24]. It is expected that the positive impact is more important than the negative impact. Especially now the mastery of the computer is needed in improving the imagination, creativity for technological progress. It can be seen that nowadays all the fields of science use the computer as a means to perform its activities. However, 
not everyone has such thoughts so there is no follow-up. Most online game addicts just want to find entertainment and satisfaction only.

\subsection{Prevention of the Addiction}

Online games have a bad impact on users, so do not become a game addict needed an effort or a way that can be done by the users of the game. There are some ways of preventing people from becoming addicted to online games such as, Strong intention to stop playing games, The first and foremost thing to be able to quit game addiction is the intention of being strong and earnest to stop playing online games. This of course cannot have a direct impact, it takes enough time so that the game addicts can really stop to play the game. The second one is a Replacing with more useful activities, replacing online gaming activities that can spend time with positive and useful activities such as reading books, taking extracurricular activities at school, following organizational activities at school and so on. Replacing useful activities so as not to feel unemployed so as not to make online games as a place of escape. Next is reduce the time to play the game, The only way you cannot get addicted to the game is to reduce game play time, which was initially done all day, minus little by little from day to day. The next way is reduce time hanging out with fellow gamers, by reducing the time meet between fellow game players can reduce game play time. Because someone is triggered to play the game because of its supportive environment. To minimize the desire to play the game is to reject the invitation and friends when invited to play the game. Get used to frugality, we need to know that playing games can actually spend a lot of money. The money is just a moment of fun and intangible nothing, so the money that should be saved will be exhausted just to play online games. Perhaps by stopping playing games will make the expenditure more efficient and can be saved to buy more useful purposes. Friends with good people, the intention of making friends with good people here is to make friends with people who do not take things that are not as useful as playing games. Befriend people who want to take care of us, who always remind us when they're wrong. And the last way is a Family Supervision. The family, especially parents is needed to know and control the activities undertaken by their child. Parents must remind a child who is too often playing the game. They should give understanding that non-stop playing is not good for them.

\section{Conclusion}

The online game addicts have some fairly common characteristics, these characteristics include: poor emotional level, lack of attention to himself, poor communication skills, laziness, always avoid something he does not like and so on. Based on some research done online game addiction has some impact that is positive and negative impact. Positive impacts such as adding new friends, being proficient in English, can increase concentration and high imagination in making strategy, on the contrary the negative impact of addiction to play online games is the social relationship to his school friends to be reduced, being indifferent to the environment, awareness of the surrounding becomes decreased, the concentration on the lesson decreases.

In addition to the psychological state also affects the physical condition of weight loss because it is too busy with the game, there is even the possibility of obesity due to uncontrolled eating, eye disorders because often see the monitor, and hand pain because too often pressing the computer buttons. Some actions to overcome the case of addiction are cultivate a strong intention to stop playing games, change the activities of playing games with more useful activities, reduce time to play games, reduce time hanging out with fellow game players, get used to frugality, making friends with good people and parental supervision.

\section{References}

[1] R. Bailey, K. Wise, and P. Bolls, "How Avatar Customizability Affect Children's Arousal and Subjective Presence During Junk Food-Sponsored Online Video Games,” Cyber Psychol. Behav., vol. 12, no. 3, pp. 277-283, 2009.

[2] V. Mallinckrodt and D. Mizerski, "The Effects of Playing an Advergame on Young Children 's Perceptions , Preferences , and Requests,” J. Advert., vol. 36, no. 2, pp. 87-100, 2014.

[3] A. Nairn, C. Fine, A. Nairn, and C. Fine, "Who's messing with my mind? The implications of dualprocess models for the ethics of advertising to children," Int. J. Advert., vol. 27, no. 3, pp. 37-41, 2015. 
[4] E. J. Jeong and D. H. Kim, "Social Activities, Self-Efficacy, Game Attitudes, and Game Addiction," Cyberpsychol. Behav. Soc. Netw., vol. 14, no. 4, pp. 213-221, 2011.

[5] J. T. Sulistyo, Evanytha, and Vinaya, "Hubungan Problematic Online Game," Psikologi, vol. 2, no. 1, pp. 396-406, 2015.

[6] M. D. Griffiths, D. J. Kuss, and D. L. King, "Video Game Addiction: Past , Present and Future," Curr. Psychiatry Rev., vol. 8, no. 4, 2012.

[7] K. H. Kim, J. Y. Park, and D. Y. Kim, "E-lifestyle and motives to use online games," Irish Mark. Rev., vol. 15, no. 2, pp. 71-77, 2002.

[8] C.-S. Wan and W.-B. Chiou, "The motivations of adolescents who are addicted to online games: a cognitive perspective," Adolescence, vol. 42, no. 165, pp. 179-197, 2007.

[9] A. F. Giandi and H. S. Arifin, "Perilaku Komunikasi Pecandu Game Online Dengan Menggunakan Game Online," e-Journal Mhs. Univ. Padjajaran, vol. 1, no. 1, pp. 1-39, 2012.

[10]K. Young, "Understanding Online Gaming Addiction and Treatment Issues for Adolescents," Americn J. Fam. Ther., vol. 37, no. 5, pp. 37-41, 2009.

[11] H. C. Chan, "Government Regulation of Online Game Addiction," Commun. theAssociation Inf. Syst., vol. 30, pp. 187-198, 2012.

[12] J. S. Lemmens, P. M. Valkenburg, and J. Peter, "Development and Validation of a Game Addiction Scale for Adolescents Development and Validation of a Game Addiction Scale for Adolescents," Media Psychol., vol. 12, no. 1, pp. 77-95, 2009.

[13] S. M. Grüsser, P. D. R. Thalemann, D. C. Ph, M. D. Griffiths, and D. Ph, "Excessive Computer Game Playing: Evidence for Addiction and Aggression ?," Cyber Psychol. Behav., vol. 10, no. 2, pp. 290-292, 2007.

[14]D. Chappell, V. Eatough, M. N. Davies, and M. Griffiths, "EverQuest-It's just a computer game right? An interpretative phenomenological analysis of online gaming addiction," Int J Ment Heal. Addict., vol. 4, no. 3, pp. 205-216, 2006.

[15]N. Yee, "Motivations for Play in Online Games," Cyber Psychol. Behav., vol. 9, no. 6, pp. 772-775, 2006.

[16] A. V Karapetsas, V. A. Karapetsas, and N. X. Zygouris, "Internet gaming addiction. Reasons, diagnosis, prevention and treatment," Encephalos, vol. 51, pp. 10-14, 2014.

[17]M. A. Liebert, Y. Chuang, and D. Ph, "Massively Multiplayer Online Role-Playing Game-Induced Seizures: A Neglected Health Problem in Internet Addiction," Cyber Psychol. Behav., vol. 9, no. 4, pp. 451-456, 2006.

[18]R. E. Kraut, P. M. Greenfield, and E. F. Gross, "Childrens activities and development," Futur. Child., vol. 10, no. 2, pp. 123-144, 2015.

[19]L. Lay, C. Teo, and R. L. Neo, "Children and Video Games: Addiction, Engagement, and Scholastic Achievement," Cyber Psychol. Behav., vol. 12, no. 5, 2009.

[20] J. E. Grant and S. Won, "Dissociative Symptoms in Pathological Gambling," Psychopathol, vol. 36, pp. 200-203, 2003.

[21]C. Koo et al., "Internet-Addicted Kids and South Korean Goverment Effort: Boot-Camp Case," Cyberpsychol. Behav. Soc. Netw., vol. 14, no. 6, 2011.

[22]D. Williams and M. Skoric, "Internet Fantasy Violence: A Test of Aggression in an Online Game," Commun. Monogr., vol. 72, no. 2, pp. 217-233, 2007.

[23]R. Syahran, "Ketergantungan online game dan penanganannya," J. Psiklogi Pendidik. Konseling, vol. 1, no. 1, pp. 84-92, 2015.

[24]J. Hong and M. Liu, "A study on thinking strategy between experts and novices of computer games," Comput. Humn Behav., vol. 19, pp. 245-258, 2003. 